\begin{tabular}{|l|l|l||}
\hline \multicolumn{2}{|c|}{ PublisherInfo } \\
\hline \hline PublisherName & $:$ & BioMed Central \\
\hline \hline PublisherLocation & $:$ & London \\
\hline \hline PublisherImprintName & $:$ & BioMed Central \\
\hline \hline
\end{tabular}

\title{
The nitroproteome
}

\begin{tabular}{|l|l|l||}
\hline \multicolumn{2}{|c|}{ ArticleInfo } \\
\hline \hline ArticleID & $:$ & 4218 \\
\hline \hline ArticleDOI & $:$ & $10.1186 /$ gb-spotlight-20011008-01 \\
\hline \hline ArticleCitationID & $:$ & spotlight-20011008-01 \\
\hline \hline ArticleSequenceNumber & $:$ & 289 \\
\hline \hline ArticleCategory & $:$ & Research news \\
\hline ArticleFirstPage & $:$ & 1 \\
\hline \hline ArticleLastPage & $:$ & 2 \\
\hline \hline & & RegistrationDate : 2001-10-08 \\
ArticleHistory & $:$ & OnlineDate $\quad$ 2001-10-08 \\
\hline \hline ArticleCopyright & $:$ & BioMed Central Ltd2001 \\
\hline \hline ArticleGrants & $:$ & \\
\hline \hline ArticleContext & $:$ & 130592211 \\
\hline \hline
\end{tabular}




\section{Jonathan B Weitzman}

Email: jonathanweitzman@hotmail.com

Protein nitration at tyrosine is associated with dozens of pathologies, including transplant rejection, cancer and Parkinson's disease. In the October 9 Proceedings of the National Academy of Sciences, Kulzant Aulak and colleagues at The Cleveland Clinic describe the use of proteomics to explore protein nitration events during inflammatory challenge (Proc Natl Acad Sci USA 2001, 98:12056-12061). They used a well-characterized monoclonal antibody recognizing nitrotyrosine to detect nitrated proteins in cytokine-stimulated human cells. Protein extracts were separated using two-dimensional gel electrophoresis and the identity of immunoreactive proteins was determined by mass spectroscopy. Manganese superoxide dismutase (MnSOD) was the predominant immunoreactive nitrated protein. Aulak et al. then used this methodology to identify nitrated proteins in the lungs and livers of rats treated with lipopolysaccharide (LPS). They detected over 40 proteins, including those involved in apoptosis, oxidative stress and metabolic pathways. This study presents a systematic experimental approach to explore the entire nitroproteome.

\section{References}

1. Biological tyrosine nitration: a pathophysiological function of nitric oxide and reactive oxygen species

2. Proceedings of the National Academy of Sciences, [http://www.pnas.org]

3. The Cleveland Clinic , [http://www.clevelandclinic.org] 